\title{
Library School Studies, 1952-53
}

\author{
Miss Cole is editor, "Library Literature," The H.W. Wilson Company.
}

$\mathrm{T}$ HE FOLLowing studies arranged by broad topics, were prepared in library schools during the above year 1952-53. Unless otherwise indicated, the studies were submitted for the master's degree.

PUBLIC RELATIONS AND EXTENSION SERVICES

Brand, Mrs. Charlotte May (Venn). Austin Public Library and the University of Texas Student. (Texas)

Vagt, John Paul. Community Services of Texas Junior College Libraries. (Texas)

\section{PERSONNEL}

Amner, Mary Case. Study of the Staff Organization and Operation of a University Library. (Kent)

Goodrich, Charlotte G. Faculty Status of Professional Library Personnel in Ohio Collegiate Institutions. (Kent)

Packard, Charles Bolles. Selection, Training, and Use of Student Assistants in the $\mathrm{Li}$ braries of the Teachers Colleges of the State of New Jersey during the Second Semester of the College Year I95I-52. (Drexel)

Park, Wilmer Reginald. Study of Certain Factors Which May Affect Work Performance of Clerical Library Assistants in the Library of the University of Texas. (Texas)

\section{SELECTION AND ACQUISITION OF PRINTED MATERIALS}

Anderson, June G. Selective List of Periodicals for Small Two-Year Colleges. (Kent)

Daly, Simeon, Father. Selection of Materials in the Field of Sacred Scripture in the Major Seminary Library with a List of Recommended Titles. (Catholic)

Flood, Robert H., Father. Selection of Materials in the Field of Canon Law in the Major Seminary Library with a List of Recommended Titles. (Catholic)

Hand, T. Spencer. Investigation of the Acquisition and $\mathrm{H}$ andling of Periodicals in
Ten College Libraries in the Philadelphia Area. (Drexel)

Ho, Dorothy. Survey of Farmington Plan Acquisition of French Books by Catholic University Library During I948-1949. (Catholic)

Wells, Harold Francis. Basic Collection for a University Departmental Library in Geography. (Washington)

Wilson, Edward, Father. Selection of $\mathrm{Ma}$ terials in the Field of Ascetical and Mystical Theology in the Major Seminary Library, with a List of Recommended Titles. (Catholic)

Zimmerman, John Jacob. Responsibility of the University Library for Collection and Preservation of Works of Minor Writers of American Fiction of the Nineteenth Century with Special Reference to the Atlanta-Athens Area, Georgia, Emory University, 1952. (Emory)

PROBLEMS OF NONPRINT MATERIALS

Jones, Carolyn Roberts. Motion Pictures in the Medical School Library. (Western Reserve)

\section{CATALOGING AND CLASSIFICATION}

Jasper, Gertrude Rathbone. Revision of the Subject Authority File of Pratt Institute Library. (Pratt)

Stein, Ruth E. Method and Cost of Establishing Adequate Records for a Departmental Book Collection within a Library. (Kent)

Tsou, Rose Chiayin. Subject Approach to the Chinese Books in the Far Eastern Library of the University of Washington. (Washington)

Walker, Lynn. Cataloging in Small College Libraries of the Southeast. (Florida State) Ward, Marietta McManigal. Plan for the 
Processing of Library Materials for the Branch Libraries at the University of Washington. (Washington)

\section{CIRCULATION}

Allen, Norma Eileen. Inter-Library Loan Program of the Library of the Western Reserve University School of Medicine. (Western Reserve)

\section{REFERENCE AND BIBLIOGRAPHY}

Alston, Annie Mae. Characteristics of Materials Used by a Selected Group of Historians in Their Research in United States History. (Chicago)

Grant, Jason Clifton. Content Analysis of Serial Publications in English Philology for a Four-Year Liberal Arts College Library. (Atlanta)

Guinivan, Ora Jane. Analysis of the Reference Service of the Kent State University Library. (Kent),

Ten Eick, Mary Nunez. Bibliographical Comparison of Twelve Selected Physiological Areas of Biological Abstracts and British Physiological Abstracts. (Florida State)

Werner, Patricia Ann. Organization of Reference Service in the Small College Library. (Drexel)

\section{USE OF THE LIBRARY}

Clarke, Jack Alden. Survey of the Use of the General Library of the University of Wisconsin by Graduate Students in the Humanities and Social Sciences. (Wiscon$\operatorname{sin)}$

Evers, Madeline C. Investigation of Student Library Usage among the Recent Graduate Students of Catholic University of America. (Catholic)

Lee, Elizabeth Cora. Use of the Card Cata$\log$ by Spelman Students in the Spelman and Trevor Arnett Libraries. (Atlanta)

Lee, Jane Daugherty. Instruction in the Use of Books and Libraries in Colleges and Universities. (Kent)

Marquis, Mary Case. Study of the Teaching of Library Facilities to College Students. (George Peabody)

Middleswart, Lilian Ellen. Study of Book Use in the University of Chicago Library. (Chicago)

Quivers, Evelyn Seace. Study of the School Library Experiences of a Selected Group of College Freshmen. (Atlanta)
Riddle, Margaret Selman. Use of the Card Catalog in the Library of a Typical Women's College. (Texas State College for Women)

Rohlf, Robert Henry. Analysis of the Characteristics of the Books Used in a University Library. (Minnesota)

Smith, Hal Haynes. Recorded Use of a University Library's Books in Two AreasBiological and Physical Sciences. (Chicago)

Smith, Yvonne Elizabeth. Instruction in the Use of the Library at Ohio Wesleyan University. (Western Reserve)

Stevens, Rolland Elwell. Use of Library Materials in Doctoral Research: a Study of the Effect of Differences in Research Method. Ph.D. (Illinois)

White, Eleanor Shirley. A Study of the Ability of Graduate Students of Atlanta University to Use the Trevor Arnett $\mathrm{Li}$ brary. (Atlanta)

Williams, Gordon Roland. Study of the Bibliographical Sources Used by The Patrons of the John Crerar Library. (Chicago)

\section{EVALUATION OF COLLECTIONS AND SERVICES}

Gearhart, Frank Hobart. Study of the Occupational Information Materials in the $\mathrm{Li}$ braries of the Carnegie Institute of Technology, the University of Pittsburgh, and Duquesne University. (Carnegie)

Gibson, Louis Edna. Study of the Vocational Guidance Materials of the Atlanta University, Spelman, Morris Brown and Clark College Libraries. (Atlanta)

McLemore, Erma Deloris. Evaluation of the Fiction Collections in the Libraries of the Atlanta University Center. (Atlanta)

Moses, Louise Jane. Evaluation of the Morris College Library, Sumter, South Carolina. (Atlanta)

Murray, Thomas Bernard. Evaluation of the Reference Collections in the Libraries of Seven San Francisco Bay Area Junior Colleges. (California)

Raser, Lois Aileen. Study of the Book Collections of Three Small Church-Sponsored Schools. (Drexel)

Williams, Gwendolyn Carter. Survey of the Periodicals Collection and General Problems Relating to the Use of Periodicals in the Libraries in the Atlanta University Center. (Atlanta) 
READING PROBLEMS

Tornudd, Elin Maria. Professional Reading Habits of Scientists Engaged in Research, as Revealed by an Analysis of I30 Questionnaires. (Carnegie)

\section{SURVEYS}

Adams, Charlcie. Kent State University Library. (Kent)

Gladeck, Alberta Alma. Library of the Franklin Institute. (Drexel)

Johnston, Pauline G. Survey of Nursing School Libraries in the City of Philadelphia. (Drexel)

Murphy, Eileen M. Study of the St. John's Law Library. (Pratt)

Pettinicchi, Arthur. Survey of the Libraries of the Religious Houses Associated with the Catholic University of America. (Catholic)

Walker, Muriel Hughes. Library of the Western Reserve Historical Society. (Kent)

\section{HISTORICAL STUDIES}

Beach, Francis Mary, Sister. History of the Library of Trinity College, Washington, D.C. (Catholic)

Bobinski, George Sylvan. Brief History of the Libraries of Western Reserve University, I 826-1952. (Western Reserve)
Bruner, Joyce Estella. History of the University of Louisville Libraries. (North Carolina)

Fortin, Clifford Charles. History of the St. Thomas College Library. (Minnesota)

Harris, Virgie. Library Development in Five Denominational Colleges in West Virginia. (Western Reserve)

Jones, Ruth. History of the Library of Teachers College, Columbia University, I887-I952. (Drexel)

Kirby, Madge Barbour. History of the Goucher College Library, I 885-1949. (Catholic)

Owings, Vivian Briggs. History of the $\mathrm{Li}$ brary of Morgan State College from 1867 to I939. (Catholic).

Stein, John H. Development of the Hiram College Library from the Literary Society Libraries Which Formed Its Nucleus. (Kent)

Wagner, Lloyd F. Descriptive History of the Library Facilities of Lafayette College, Eaton, Pennsylvania, I824-I94I. (Catholic)

\section{UNIVERSITY PRESSES}

Gaylord, Charlotte G. Study of Louisiana State University Press. (George Peabody)

Klanian, Mary. University of Pennsylvania Press, i 870-1952. (Drexel)

\section{Centenary Junior College Library Building}

Construction of a $\$ 312,000$ library building is well under way on the campus of Centenary Junior College, Hackettstown, New Jersey. The ground was officially broken for the William H. and May D. Taylor memorial building shortly after school closed in June. The library is part of an extensive program of expansion which has seen the addition of five buildings to the campus the past five years.

The new library is dedicated to the memory of William H. and May D. Taylor of Yonkers, New York, and Gloucester, Massachusetts, who were students in the college when it was coeducational. The Surdna Foundation of Yonkers, with which Mr. and Mrs. Taylor were long connected, gave the largest gift for the construction of this building honoring these two friends of the college and the foundation.

The library will have a circulation lobby and reference area, a reading room and two stack levels, a music listening room and cubicles, Centenariana-Conference room, seminar and library instruction class rooms, a student lounge, a periodical-recreational reading area, offices for librarian and assistant, and a large work room. There will be a faculty-staff reading lounge, storage room, and the Cummins Museum, named after Annie Blair Titman Cummins of Belvidere, whose estate was recently left to the college by will.

The library is a much needed addition to the campus of Centenary for the enrolment as the institution has increased from a student body of 159 students in 1943 to one of 429 in 1953 . The buildings are to be completed by graduation time next year. 